\title{
FAKTOR-FAKTOR YANG MEMPENGARUHI ORANG TUA DALAM MEMILIH ALAT PERMAINAN PADA ANAK USIA 1-5 TAHUN DI RW VI DEMAK TIMUR SURABAYA
}

\author{
*Ni putu Widari ** Ethyca Sari \\ AKPER William Booth, Jl. Cimanuk No: Surabaya Telp:031-5633365
}

\begin{abstract}
ABSTRAK
Dunia anak adalah dunia bermain. Melalui kegiatan bermain, semua aspek perkembangan anak yang di tumbuhkan secara optimal dan maksimal anak-anak menjadi lebih sehat sekaligus cerdas. Melalui kegiatan bermain, daya pikir anak terangsang untuk mendayagunakan aspek emosional, sosial serta fisiknya. Bermain juga dapat meningkatkan kemampuan fisik, pengalaman dan pengetahuannya, serta berkembang keseimbangan mental anak. Banyak ditemukan anak yang pada masa tumbuh kembangnya mengalami keterlambatan yang dapat disebabkan oleh kurangnya pemenuhan kebutuhan pada diri anak, termasuk di dalamnya adalah kebutuhan bermain. Masa kanakkanak seharusnya merupakan masa bermain yang diharapkan dapat menumbuhkan kematangan dalam pertumbuhan dan perkembangan, sehingga apabila masa tersebut tidak digunakan sebaik mungkin maka akhirnya akan mengganggu tumbuh kembang anak .Desain penelitian yang digunakan adalah metode deskriptif dengan uji statistik Wilcoxon . Pada penelitian ini populasinya adalah orang tua yang memiliki anak dengan usia 1-5 tahun di wilayah Demak timur RW VI Surabaya. Alat ukur yang digunakan pada saat pengumpulan data adalah dengan menggunakan lembar kuisoner .Diidapatkan hasil bahwa Faktor lingkungan mempengaruhi ibu dalam memilih alat bermain pada anak usia 1-5 tahun sebanyak $30 \mathrm{ibu}(100 \%)$,Faktor keselamatan mempengaruhi ibu dalam memilih alat bermain pada anak usia 1-5 tahun sebanyak 29 ibu (90\%). Faktor harga mempengaruhi ibu dalam memilih alat bermain pada anak usia 1-5 tahun sebanyak 26 ibu (86,6\%). Diharapkan dalam memilih alat permainan bagi balita hendaknya memilih permainan yang disesuaikan dengan usia anak dan disesuaikan dengan fungsi dari mainan itu sendiri, sehingga alat permainan anak akan dapat membantu menstimulasi dari kecerdasan dari anak
\end{abstract}

Kata kunci : Orang tua, anak usia 1-5 tahun, faktor yang mempengaruhi

\section{Pendahuluan}

Dunia anak adalah dunia bermain. Melalui kegiatan bermain, semua aspek perkembangan anak yang di tumbuhkan secara optimal dan maksimal anak-anak menjadi lebih sehat sekaligus cerdas. Melalui kegiatan bermain, daya pikir anak terangsang untuk mendayagunakan aspek emosional, sosial serta fisiknya. Bermain juga dapat meningkatkan kemampuan fisik, pengalaman dan pengetahuannya, serta berkembang keseimbangan mental anak. Banyak ditemukan anak yang pada masa tumbuh kembangnya mengalami keterlambatan yang dapat disebabkan oleh kurangnya pemenuhan kebutuhan pada diri anak, termasuk di dalamnya adalah kebutuhan bermain.. Masa kanak-kanak seharusnya merupakan masa bermain yang diharapkan dapat menumbuhkan kematangan dalam pertumbuhan dan perkembangan, sehingga apabila masa tersebut tidak digunakan sebaik mungkin maka akhirnya akan mengganggu tumbuh kembang anak. Dalam memilih permainan pada anak hendaknya di sesuaikan dengan jenis kelamin, umur pertumbuhan dan perkembangan anak. Dengan memilih alat bermain yang sesuai dengan pertumbuhan dan perkembangan anak akan mempunyai danpak yang positif, demikian juga sebaliknya terhadap perkembangan anaknya. Misalnya playstation yang dapat mengganggu perkembangan sosial anak, pedang-pedangan dan pistol yang berisi peluru karet yang dapat melukai dan mencelakakan diri sendiri dan temannya, dan permainan ding-dong yang mana warnawarna pada mesin dapat membuat mata rusak, keasyikan bermain juga dapat membuat anak malas belajar. (Notoadmojo, 2003).

Pada fenomena yang dilihat oleh peneliti kebanyakan orang tua memberikan alat permaianan sesuai dengan selera anak, sehingga anak-anak yang seharusnya bermain sesuai dengan usia maupun perkembangannya cenderung menggunakan alat bermain tersebut 
menjadi sesuatu yang bisa membahayakan bagi pertumbuhan maupun perkembangan anak tersebut. Pengetahuan adalah keseluruhan pemikiran, gagasan, konsep, ide, dan dan pemahaman yang dimiliki manusia tentang dunia dan isinya termasuk manusia dan kehidupannya pengetahuan mencakup penalaran, penjelasan dan pemahaman manusia tentang segala sesuatu. Sepengetahuan orang tua terhadap alat bermain sangat diperlukan karena bahaya yang ditimbulkan sangat mempengaruhi lingkungan maupuan perkembangan jiwa anak .

Berdasarkan study pendahuluan yang dilakukan di wilayah Demak Timur RW VI Surabaya, masih banyak orang tua yang tidak mengetahui pemilihan alat bermain yang sesuai dengan usia anak. Dari 10 responden ibu yang dan diberikan beberapa pertanyaan contoh: ibu tahu tidak alat bermain sesuai dengan usia anak ibu yang sekarang berusia 3 tahun bahaya penggunaan alat bermain yang tidak sesuai dengan usia. Didapatkan 6 orang mengatakan tidak mengetahui alat bermain sesuai dengan usia anak dan 4 orang menjawab pertanyaan tentang alat bermain sesuai dengan usia anak. Kurangnya pengetahuan orang tua dalam memilih alat atau jenis permainan dapat berdampak negatif, yaitu orang tua tidak memperhatikan fungsi dan manfaat dari alat atau jenis permainan yang mereka belikan untuk anak-anaknya. Banyak ditemukan anak pada masa tumbuh kembangnya mengalami keterlambatan yang dapat disebabkan oleh kurangnya pemenuhan kebutuhan pada diri anak, termasuk di dalamnya adalah kebutuhan bermain. Oleh karena itu, jenis dan fungsi permainan sangatlah penting dan dapat berpengaruh terhadap perkembangan seperti sosialisasi anak, motorik halus dan motorik kasar (Aziz Alimul Hidayat, 2011) . Dampak yang bisa dilihat jika orang tua kurang pengetahuan didalam memilih jenis alat bermain maka yang terjadi anak bisa tumbuh dan berkembang tidak sesuai dengan usianya contoh : anak umur 3 tahun diberikan mainan pistol mainan isi peluru karet, maka dalam pola pikir anak tersebut dia sudah mengenal kekerasan dan yang menjadi lawan adalah temannya sendiri, dan dapat melukai diri sendiri dan teman mainnya, hal ini juga akan menimbulkan keegoisan pada anak sampai tumbuh dewasa.
Pemilihan alat bermain yang tepat sesuai dengan usia anak merupakan cara yang sederhana tapi sangat bermanfaat dalam membantu stimulasi perkembangan dan pertumbuhan anak baik motorik, sensorik, kognitif, sosial, moral, dan kreatifitas. Orang tua dalam hal ini harus benar-benar memperhatikan jenis dan kegunaan alat permainan bagi anak yang sesuai. Alat permainan biasanya di buat dari berbagai bahan atau zat yang berbahaya bagi kesehatan, hal ini biasanya banyak di temukan pada merk yang tidak memiliki ijin resmi dari pemerintah. Sebagai orang tua harus benarbenar memperhatikan jenis, fungsi dan lebel peringatan yang ada pada kemasan atau bungkus alat pemainan, apakah di dalam alat permainan tersebut terdapat zat yang berbahaya atau tidak bagi kesehatan. Berdasarkan hal di atas maka, peneliti tertarik untuk meneliti tentang Faktor faktor yang mempengaruhi orang tua dalam memilih alat bermain usia 1-5 tahun

\section{Metode}

Pada bab ini berisi tentang desain penelitian, kerangka kerja, populasi, sampel dan sampling, identifikasi variabel dan identifikasi operasional, mengumpulkan datam, analisa data, masalah etika

Desain penelitian sebagai petunjuk peneliti dalam perencanaan dan pelaksanaan penelitian untuk mencapai suatu tujuan atau jawaban - jawaban serta pertanyaan. Dalam penelitian ini desain penelitian yang digunakan adalah metode deskriptif untuk menggambarkan faktor dominan yang mempengaruhi orang tua dalam memilih alat bermain pada anak usia 1-5 tahun. Penelitian ini dilakukan pada bulan Mei tahun 2015 di RW VI Demak Timur Surabaya

Pada penelitian ini populasinya adalah orang tua yang memiliki anak dengan usia 15 tahun di wilayah Demak timur RW VI Surabaya. Sampelnya adalah ibu yang memiliki dengan anak usia $1-5$ tahun di wilayah Demak Timur RW VI Surabaya.

\section{Hasil}

Gambaran Umum

Penelitian ini dilakukan di RW VI Demak Timur Surabaya yang terdiri dari 13 Rukun Tetangga ( RT ) masing - masing RT terdiri dari lebih kurang 80 sampai dengan 100 kepala keluarga dengan berbagai karakter 
berbeda dengan latar belaang sebagian besar dari suku madura, dengan karakteristi kampung padat penduduk. RW VI Demak Timur ini dibatasi dengan beberapa wilayah antara lain sebelah barat Pasar Turi Grosir Surabaya, sebelah timur pasar Blauran Surabauya, Wilayah Selatan Pasar Loak Surabaya, dan sebelah Utara Tanjung Perak Surabaya. RW VI Demak Timur merupakan wilayah yang sering menjuarai perlombaan kebersihan dan lingkungan penghijauan sekotamadya Surabaya, hal ini menunjukan bahwa meskipun warga diwilayah tersebut sangat padat tetapi kesadaran masyarakat atau warga ditempat tersebut sangat tinggi dalam menjaga lingkungan tempat tinggalnya.

Karakteristik Responden

Responden penelitian ini adalah ibu yang mempunyai anak usia 1-5 tahun . Jumlah sampel dalam penelitian ini adalah sebanyak $30 \mathrm{ibu}$ yang mempunyai anak usia 1-5 tahun dan yang akan diberikan kuisioner Faktorfaktor yang mempengaruhi ibu dalam memilih alat permaianan anak usia 1-5 tahun.

Data Umum

Data umum ini menggambarkan tentang karakteristik responden. Pada penelitian ini data umum terbagi menjadi karakteristik usia, umur dan pekerjaan responden

Karakteristik responden berdasarkan pendidikan

Tabel 1 Karakteristik Pendidikan ibu yang mempunyai anak usia 1-5 tahun dalam memilih alat permaianan di RW VI Demak Timur Surabaya, Mei 2015

\begin{tabular}{ccc}
\hline $\begin{array}{c}\text { Kelompok } \\
\text { Pendidikan }\end{array}$ & Nilai & Prosentase \\
\hline Tidak Sekolah & 1 & $3 \%$ \\
SD & 14 & $48 \%$ \\
SMP & 7 & $25 \%$ \\
SMA & 4 & $14 \%$ \\
Perguruan & 3 & $10 \%$ \\
Tinggi & & $100 \%$ \\
Jumlah & 30 & hasil \\
\hline Berdasarkan tabel & diatas didapatkan \\
sebagian besar ibu berpendidikan SD.
\end{tabular}

Karakteristik responden berdasarkan usia

Tabel 2 Karakteristik Usia ibu yang mempunyai anak usia 1-5 tahun dalam memilih alat permaianan di RW VI Demak Timur Surabaya, Mei 2015

\begin{tabular}{ccc}
\hline $\begin{array}{c}\text { Kelompok } \\
\text { Usia }\end{array}$ & Nilai & Prosentase \\
\hline $21-25$ tahun & 9 & $30 \%$ \\
$26-30$ tahun & 17 & $56 \%$ \\
$31-35$ tahun & 4 & $14 \%$ \\
35-40 tahun & 0 & $0 \%$ \\
Jumlah & 30 & $100 \%$ \\
\hline
\end{tabular}

Berdasarkan tabel diatas didapatkan hasil sebagian besar responden berusia 26-30 tahun sebanyak 17 responden $(56 \%)$

Karakteristik responden berdasarkan pekerjanaan

Tabel 3 Karakteristik Pekerjaan ibu yang mempunyai anak usia 1-5 tahun dalam memilih alat permaianan di RW VI Demak Timur Surabaya

\begin{tabular}{ccc}
\hline $\begin{array}{c}\text { Kelompok } \\
\text { Usia }\end{array}$ & Nilai & Prosentase \\
\hline Tidak Bekerja & 11 & $35 \%$ \\
Wiraswasta & 14 & $48 \%$ \\
Pegawai Negeri & 3 & $10 \%$ \\
Swasta & 2 & $7 \%$ \\
Jumlah & & $100 \%$ \\
\hline
\end{tabular}

Berdasarkan tabel diatas didapatka hasil bahwa responden memiliki pekerjaan sebagai wiraswasta sebanyak 14 responden (48\%).

Data Khusus

Karakteristik Faktor Keselamatan

Tabel 4 Karakteristik Faktor Keselamatan yang mempengaruhi ibu yang mempunyai anak usia memilih alat permaianan di RW VI Demak Timur Surabaya

\begin{tabular}{|c|c|c|}
\hline $\begin{array}{l}\text { Faktor } \\
\text { Keselamatan }\end{array}$ & Nilai & Prosentase \\
\hline Mempengaruhi & 27 & $90 \%$ \\
\hline Tidak & 3 & $10 \%$ \\
\hline Mempengaruhi & & \\
\hline Jumlah & 30 & $100 \%$ \\
\hline
\end{tabular}


tahun di RW VI Demak Timur sebanyak 27 responden $(90 \%)$

\section{Karakteristik Faktor Harga}

Tabel 5 Karakteristik Faktor Harga yang mempengaruhi ibu yang mempunyai anak usia 1-5 tahun dalam memilih alat permaianan di RW VI Demak Timur Surabaya

\begin{tabular}{lcc}
\hline Kesehatan & Nilai & Prosentase \\
\hline $\begin{array}{c}\text { Mempengaruhi } \\
\text { Tidak }\end{array}$ & 26 & $86,6 \%$ \\
$\begin{array}{c}\text { mempengaruhi } \\
\text { Jumlah }\end{array}$ & 40 & $13,4 \%$ \\
\hline Berdasarakan tabel & diatas di dapatkan hasil \\
bahwa faktor harga mempengaruhi ibu dalam \\
memeilih permainan pada anak usia 1-5 tahun \\
di RW VI Demak Timur sebanyak 26 \\
responden $(86,6 \%)$.
\end{tabular}

Karakteristik Faktor Lingkungan

Tabel 6 Karakteristik Faktor lingkungan yang mempengaruhi ibu yang mempunyai anak usia 1-5 tahun dalam memilih alat permaianan di RW VI Demak Timur Surabaya

\begin{tabular}{ccc}
\hline Lingkungan & Nilai & Prosentase \\
\hline Mempengaruhi & 30 & $100 \%$ \\
$\begin{array}{c}\text { Tidak } \\
\text { mempengaruhi }\end{array}$ & - & - \\
Jumlah & 30 & $100 \%$ \\
\hline
\end{tabular}

Berdasarakan tabel diatas di dapatkan hasil bahwa faktor lingkungan mempengaruhi ibu dalam memeilih permainan pada anak usia 1-5 tahun di RW VI Demak Timur sebanyak 30 responden $(100 \%)$

\section{Pembahasan}

Berdasarkan tabel 4 didapatkan faktor keselamatan dari permainan yang mempengaruhi ibu dalam pemilihan mainan pada usia 1-5 tahun di RW VI Demak Timur Surabaya yaitu sebanyak 27 responden (90\%). Bermain merupakan kegiatan yang dilakukan secara sukarela untuk memperoleh kesenangan/kepuasan. Bermain merupakan kemampuan fisik, intelektual, emosional dan sosia, dan bermain merupakan media yang baik untuk belajar karena dengan bermain anak-anak akan berkata-kata (berkomunikasi), belajar menyesuaikan diri dengan lingkungan, melakukan apa yang dapat dilakukan, dan mengenal waktu serta suara. (Wong, 2000). Setiap orang tua selalu mencemaskan keselamatan anaknya. Biasanya, ada mainan dengan peringatan keselamatan di kemasan seperti jangan memasuk mainan dalam mulut, jadi pastikan Anda menyimpan benda-benda berbahaya seperti yang terbuat dari plastik dan bentuk yg kecil- kecil dari anak Anda. Pengetahuan oran tua akan pentingnya bahaya keselamatan bagi anaknya akan sangat mempengaruhi kemanan dari penggunaan permainan. Orang tua harus mengetahui bahaya bahaya yang tersembunyi saat alat permainan itu digunakan bagi anaknya. Beberapa faktor di prediksi berperan dalam keputusan ibu dalam memilih permainan bagi anaknya yang berusia 1- 5 tahun diantaranya adalah pendidikan ibu, usia ibu dan pekerjaan ibu.

Berdasarkan tabel 5 didapatkan faktor harga dari permainan yang mempengaruhi ibu dalam pemilihan mainan pada usia 1-5 tahun di RW VI Demak Timur Surabaya yaitu sebanyak 26 responden $(86,6 \%)$. Dunia anak adalah dunia bermain. Melalui bermain, semua aspek perkembangan anak ditumbuhkan sehingga anak-anak menjadi lebih sehat sekaligus cerdas. Saat bermain, anak-anak mempelajari banyak hal penting. Sebagai contoh, dengan bermain bersama teman, anak-anak akan lebih terasah rasa empatinya, mereka juga bisa mengatasi penolakan dan dominasi, serta bisa mengelola emosi. Aspek perkembangan anak dapat ditumbuhkan secara optimal dan maximal melalui kegiatan bermain. Mengajak anakanak bermain pada usia pra sekolah telah terbukti mampu meningkatkan perkembangan mental dan kecerdasan anak, bahkan jika anak tersebut mengalami malnutrisi. Melalui kegiatan bermain, daya pikir anak terangsang untuk mendayagunakan aspek emosional, sosial, serta fisiknya. Selain itu, anak-anak juga dapat mempelajari banyak hal, misalnya dengan bermain ayunan anak secara tidak langsung melatih keseimbangan fisik dan psikisnya, bermain komidi putar dapat melatih keberanian dan ekspresi emosionalnya dalam segala situasi dan kondisi.

Anak-anak bermain dengan menggunakan seluruh emosinya, perasaannya, 
dan pikirannya. Kesenangan merupakan salah satu elemen pokok dalam bermain. Anak akan terus bermain sepanjang aktivitas tersebut menghiburnya. Pada saat mereka bosan, mereka akan berhenti bermain. Hal inilah yang membuat orang tua cenderung memlihkan berbagai permainan dan alat permainan yang bervariasi untuk menghindari kebosanana dari anak. Orang tua akan berusana memberikan permainan kepada anaknya tanpa memikirkan harga mahal atau murahnya alat permainan tersebutn yang terpenting adalah anak senang dan tidak merasa bosan. Jika kita bisa mendapatkan mainan tertentu dengan harga lebih murah, tetapi dengan fungsi yang sama dengan yang lebih mahal, biasanya kita akan membeli yang lebih murah. Jangan berinvestasi dalam mainan yang sangat mahal, terutama jika tahap anak Anda berada pada keadaan cepat perubahan ada kemungkinan dia akan kehilangan minat pada mainan di waktu yang sangat singkat.

Berdasarkan tabel 6 didapatkan faktor lingkungan (area permainan) dalam penggunan dari permainan yang mempengaruhi ibu dalam pemilihan mainan pada usia 1-5 tahun di RW VI Demak Timur Surabaya yaitu sebanyak 30 responden (100\%). Dunia anak adalah dunia bermain. Melalui bermain, semua aspek perkembangan anak ditumbuhkan sehingga anak-anak menjadi lebih sehat sekaligus cerdas. Saat bermain, anak-anak mempelajari banyak hal penting. Sebagai contoh, dengan bermain bersama teman, anak-anak akan lebih terasah rasa empatinya, mereka juga bisa mengatasi penolakan dan dominasi, serta bisa mengelola emosi. Aspek perkembangan anak dapat ditumbuhkan secara optimal dan maximal melalui kegiatan bermain. Mengajak anakanak bermain pada usia pra sekolah telah terbukti mampu meningkatkan perkembangan mental dan kecerdasan anak, bahkan jika anak tersebut mengalami malnutrisi. Melalui kegiatan bermain, daya pikir anak terangsang untuk mendayagunakan aspek emosional, sosial, serta fisiknya. Selain itu, anak-anak juga dapat mempelajari banyak hal, misalnya dengan bermain ayunan anak secara tidak langsung melatih keseimbangan fisik dan psikisnya, bermain komidi putar dapat melatih keberanian dan ekspresi emosionalnya dalam segala situasi dan kondisi.
Anak-anak bermain dengan menggunakan seluruh emosinya, perasaannya, dan pikirannya. Kesenangan merupakan salah satu elemen pokok dalam bermain. Anak akan terus bermain sepanjang aktivitas tersebut menghiburnya. Pada saat mereka bosan, mereka akan berhenti bermain. Pemilihan area dalam melakukan permainan akan membuat anak akan lebih menin $k$ mati alat permainan yang dimiliki. Alat permainan yang kecil dan simpel tidak membutuhkan area bermain yang luas, tetapi alat permainan yang besar seperti bola membutuhkan area bermain yang lebih luas sehingga anak dapat mengekspresikan luapan kegembiraan saat bermain bola. Orang tua hendaknya bijaksana dalam memilihkan alat permainan bagi anaknya yang disesuaikan dengan tempat dimana alat permainan itu dimainkan. Dengan demikian anak akan dapat berembang dengan optimal dengan alat permainan yang dipilihkan orang tuanya terutama ibu.

\section{Kesimpulan}

Faktor lingkungan mempengaruhi ibu dalam memilih alat bermain pada anak usia 1-5 tahun sebanyak $30 \mathrm{ibu}(100 \%)$.

Faktor keselamatan mempengaruhi ibu dalam memilih alat bermain pada anak usia 1-5 tahun sebanyak $29 \mathrm{ibu}(90 \%)$.

Faktor harga mempengaruhi ibu dalam memilih alat bermain pada anak usia 1-5 tahun sebanyak 26 ibu (86,6\%).

\section{Saran}

Bagi Responden

Diharapkan dalam memilih alat permainan bagi balita hendaknya memilih permainan yang disesuaikan dengan usia anak dan disesuaikan dengan fungsi dari mainan itu sendiri, sehingga alat permainan anak akan dapat membantu menstimulasi dari kecerdasan dari anak

Bagi Peneliti

Diharapkan penelitian ini dapat dijadika acuan untuk mengembangkan penelitian yang serupa tetapi dengan memperbaiki dari alat ukur dan mempertimbangkan faktor faktor yang lain selain faktor diatas.

\section{Daftar Pustaka}

Agustiani, Dr. Hendriani, 2006, Psikologi Perkembangan Bandung: PT Refika Aditama 
Alimul, Azis. 2003. Riset Keperawatan Sebuah Karya Tulis Ilmiah. Jakarta:Salemba media.

Arikunto, S. 2001. Prosedur Penelitian Suatu Pendekatan Praktek. Jakarta:Rineka cipta.

Azwar, Syaifuddin, 2013, Penyusunan Skala psikologi, Yogyakarta, Pustaka pelajar

Cindy, S.G, 1988, Nursing Care Planning Guides for ldren

Soetjningsih, dr,SpAk, 1995, Tumbuh Kembang Anak, Penerbit Buku Kedokteran EGC: Jakarta

Mansjoer, Arif. 2001. Kapita Selekta, Edisi Ketiga, Jilid I : 476. Jakarta : Penerbit Fakultas Kedokteran UI.

http : // diunduh Viethanurse. Wordpress. Com/2009.

Tambayon, Jan. 2001. Anatomi dan Fisiologi untuk Keperawatan. Jakarta : Penerbit Kedokteran EGC.

Kamus Kedokteran Porlan, Edisi 29. Jakarta : EGC

Ngastiyah. 1997. Perawatan Anak Sakit. Jakarta : EGC.C

Capernito, Lynda. 2000. Diagnosa Keperawatan Aplikasi Pada Praktik Klinis. Jakarta: EGC.

Betz Cecily, Linda A Sowden. 2002. Buku Saku Keperawatan Pediatrik. Jakarta : EGC. 